\title{
Response of Plant Geometry, Graded Fertility and Zinc Level on Productivity, Profitability and Quality of Rainfed Baby corn (Zea mays L.) in Bihar
}

\author{
Alka Jyoti Sharma ${ }^{1}$, M. K. Singh ${ }^{1}$, Sanjay Kumar ${ }^{1}$ and Shweta Shambhavi ${ }^{2}$ \\ ${ }^{1}$ Department of Agronomy, Bihar Agricultural University Sabour, \\ ${ }^{2}$ Department of Soil Science and Agricultural Chemistry, Bihar Agricultural University \\ Sabour, Bhagalpur, India \\ *Corresponding author
}

\section{Keywords}

Plant geometry, Fertility, Zinc, Productivity, Profitability, Quality, Baby corn

Article Info

Accepted:

15 January 2020

Available Online:

10 February 2020

\section{A B S T R A C T}

A Field experiments were carried out on sandy loam soil at Sabour during kharif season of 2018 to evaluate optimum plant geometry, fertility levels and zinc level for baby corn (Zea mays L.) productivity and quality. Experiment was laid out in split-plot design and replicated thrice with three plant geometry level viz. $\mathrm{P}_{1}(40 \mathrm{X} 20 \mathrm{~cm}), \mathrm{P}_{2}(50 \mathrm{X} 15 \mathrm{~cm})$ and $\mathrm{P}_{3}$ ( paired row at $50+30 \times 20 \mathrm{~cm}$ ) in main plot, three graded levels of fertility (kg NPK/ha) viz. $F_{1}(120: 60: 60), F_{2}(150: 75: 75)$ and $F_{3}$ (180:90:90) in sub plot whereas, two levels of zinc (kg/ha) viz, $Z_{1}(2.5)$ and $Z_{2}(5.0)$ in sub-sub plot. Significant increase in baby corn yield (14.34 q ha-1), green fodder yield (267.822 q ha' ${ }^{-1}$, net return (Rs $\left.225774 \mathrm{ha}^{-1}\right), \mathrm{B}: \mathrm{C}$ ratio (5.12) and quality of baby corn were recorded with paired row plant geometry. The baby corn yield (13.92 q ha $\mathrm{q}^{-1}$, green fodder yield (278.91q ha ${ }^{-1}$ ), net return (Rs 219108 $\mathrm{ha}^{-1}$ ), B:C ratio (4.81) and quality was fetched with graded fertility level 180:90:90 kg N $\mathrm{P}_{2} \mathrm{O}_{5} \quad \mathrm{~K}_{2} \mathrm{O} /$ ha which remained significantly superior over preceding level of fertility. Higher level of zinc had improved baby corn yield $\left(13.38 \mathrm{q} \mathrm{ha} \mathrm{h}^{-1}\right)$, green fodder yield $\left(277.7 \mathrm{q} \mathrm{ha}{ }^{-1}\right.$ ), net return ( $\left.\mathrm{Rs} 211821 \mathrm{ha}^{-1}\right), \mathrm{B}: \mathrm{C}$ ratio (4.77) and quality upto $\mathrm{Zn}_{2}(5.0 \mathrm{~kg}$ $\mathrm{ha}^{-1}$ ) level of zinc.

\section{Introduction}

Maize (Zea mays L.) is grown on an area of $9.5 \mathrm{~m}$ ha, with production and productivity of $25.0 \mathrm{mt}$ and $26.3 \mathrm{q} \mathrm{ha}^{-1}$, respectively (Anon.2018) in India. Maize assumes a special significance in Indian agriculture on account of its utilization as food, feed, fodder, silage and baby corn besides several industrial uses. In India, Maize is grown though out the year under cereal crop due to photo thermal insensitive characters. The productivity of maize affected by various factors including weather, plant geometry and nutrients. Baby corn is the unfertilized, dehusked tender maize cob plucked at $2-3 \mathrm{~cm}$ silk stage. The crispy nature of baby corn and its high nutritional value (86-89 \% moisture, $8.2 \mathrm{~g}$ carbohydrate, $2 \mathrm{~g}$ protein, $0.2 \mathrm{~g}$ fat, $0.28 \mathrm{mg}$ calcium, $0.86 \mathrm{mg}$ phosphorus, $0.11 \mathrm{mg}$ iron, 
$0.05 \mathrm{mg}$ thiamin, $0.08 \mathrm{mg}$ riboflavin, $11 \mathrm{mg}$ ascorbic acid per $100 \mathrm{~g}$ of fresh baby corn) has made it of special choice among the elite group of people (Das et al., 2009) ${ }^{3}$. Its consumption is considered ecofriendly because it is free from the residue of pesticides by virtue of natural protection through many layers of husk. After harvesting of baby corn, quality palatable green fodder is used for cattle feed. At the same time it will also strengthen the cropping system (ricewheat) and explore the possibilities of generating more income and employment for farming community of the region especially in periurban areas. Baby corn may be grown as a best substitute of grain maize to get better economic returns because it is harvested in short duration (within 65-70 days) which provides sweet, succulent and delicious green cobs. The short duration of the crop enables it to escape from many abiotic stresses expected to occur in the later part of the season. It is emerging worldwide as one of the high value crops due to its high nutritive value, delicious taste, low calorie vegetable having higher fiber content without cholesterol and very large demand by the foreign tourists. Crop geometry vary widely in different parts of the world because great abundance of maize strains and their distribution all over the globe in different climatic conditions. Crop geometry is one of the important factors for higher production as it determines the optimum plant population of a crop. Baby corn is heavy feeder of nutrients, its productivity is largely dependent on nutrient management. Their application may assist in obtaining maximum production of baby corn, but the excessive use of chemical fertilizers has been associated with decline in soil physical and chemical properties and crop yield (Kumar et al., 2016). Zinc plays role in various metabolic functions and enhances synthesis of growth hormones and protein. It is needed in the production of chlorophyll and metabolism of carbohydrate.

\section{Materials and Methods}

A experiment was carried out at Research farm, Bihar Agricultural University, Sabour during kharif season of 2018 under rainfed condition. The farm is situated at $25^{\circ} 50^{\prime} \mathrm{N}$ latitude, $87^{\circ} 19^{\prime} \mathrm{E}$ longitude and at an altitude of $52.73 \mathrm{~m}$ above mean sea level. The sandyloam soil of the experimental field was low in organic carbon $(0.50 \%)$ and available $\mathrm{N}$ $(182.3 \mathrm{~kg} / \mathrm{ha})$, medium in available $\mathrm{P}$ (37.7 $\mathrm{kg} / \mathrm{ha})$ and $\mathrm{K}(190.7 \mathrm{~kg} / \mathrm{ha})$ with $\mathrm{pH}$ 7.5. The experiment was laid out in split-plot design with three level of plant geometry viz. $\mathrm{P}_{1}$ $(40 \mathrm{X} 20 \mathrm{~cm}), \mathrm{P}_{2}(50 \mathrm{X} 15 \mathrm{~cm})$ and $\mathrm{P}_{3}$ (paired row at $50+30 \times 20 \mathrm{~cm}$ ) in main plot, three levels of fertility (kg NPK/ha) viz. $F_{1}(120: 60: 60), \quad F_{2} \quad(150: 75: 75)$ and $F_{3}$ (180:90:90) in sub plot whereas, two levels of zinc ( $\mathrm{kg} / \mathrm{ha})$ viz, $\mathrm{Z}_{1}(2.5)$ and $\mathrm{Z}_{2}(5.0)$ in subsub plot and replicated thrice. Crop was sown on $2^{\text {nd }}$ June 2018 on levelled soil by opening 5 $\mathrm{cm}$ deep furrow at as per spacing of treatments. The different doses of graded fertilizers were applied as per the treatments. Full amount of phosphatic and potassic fertilizer, zinc and half amount of nitrogenous fertilizer were applied as uniformly as possible before sowing.

The rest half of the nitrogenous fertilizer was applied as top dressing during the time of earthing up and detasseling stage. The field was kept free from weeds. Harvesting of baby corn was done at 2-3 days of silk emergence stage by leaving border rows. These baby cobs were counted weighted and thereafter husked and silk was removed and baby corn yield was recorded. Total rain fall received during crop period was $370 \mathrm{~mm}$ with 17 rainy days.

\section{Chemical analysis}

Baby corn sample collected and followed the standard procedure for the chemical analysis. 


\section{Reducing sugar}

Lane and Eynon (1923) copper titration method was used for the determined of sugar content in baby corn was as per method described. Distilled water was added to Fehlings solution of $\mathrm{A}$ and $\mathrm{B}(5 \mathrm{ml}$ each) which were taken in a conical flask and 10 $\mathrm{ml}$. The sample juice was titrated against boiling Fehlings solution and indicator Methlene blue was used. Brick red colour determined the end point of titration. Considering $10 \mathrm{ml}$ of Fehling solution A and $\mathrm{B}$ equal to 0.05 of glucose the reducing sugar was estimated in percentage in the juice.

\section{Total sugar}

Lane and Eynon (1923) copper titration method was used. $50 \mathrm{ml}$ of juice was taken, 5 $\mathrm{ml}$ of concentrated HCL was added and let it 24 hours undisturbed. Then neutralized it with $40 \%$ sodium hydroxide solution. Adding two drops of phenolphthalein indicator prior to neutralization. For testing blue and red litmus paper were used for complete neutralization. Titration against Fehling solution A and B as in the case of reducing sugar. The amount of total sugar in juice was worked out considering $10 \mathrm{ml}$ of Fehling solution A and $\mathrm{B}$ equal to $0.05 \mathrm{~g}$ of glucose.

\section{Nitrogen and protein content (\%)}

Nitrogen content in the crushed baby corn was estimated by Kjeldahl method and multiplied by 5.95 (Lu and Luh, 1991) to get crude protein content.

\section{Phosphorus content (\%)}

Phosphorus was estimated by Vandomolybdo-phosphoric acid yellow colour method using the Barton's reagent as suggested by (Jackson, 1973).

\section{Potassium content (\%)}

The potassium was determined with the help of flame photometer.

\section{Zinc content (\%)}

The zinc content was determined via atomic absorbtion spectrophotometer.

\section{Statistical analysis}

The data on various observations were statistically analyzed by the procedure of analysis of variance for split-plot design (SPD) given by Panse and Sukhatma (1985). For significant ' $F$ ' test, critical difference (CD) was reported at 5 per cent probability level.

\section{Results and Discussion}

Effect of plant geometry, fertility and zinc on yield of baby corn

Significantly higher baby cob yield $(54.91 \mathrm{q}$ $\mathrm{ha}^{-1}$ ) and baby corn yield (14.34 $\mathrm{q} \mathrm{ha}^{-1}$ ) were recorded with paired row planting. The crop under the wider inter row spacing has utilized the available resources more efficiently and hence, producing more yield attributes helped to higher cob yield. The crop under closer geometry at $50 \mathrm{~cm} \times 15 \mathrm{~cm}$ of plant geometry exhibited highest green fodder yield $(284.24 \mathrm{q}$ $\mathrm{ha}^{-1}$ ) as compared to the wider geometry. The fodder yield might have compensated these because of more number of plants $\mathrm{ha}^{-1}$. The result is similar to the findings of Mathukia $e t$ al. (2014) and Singh et al. (2015).

Fertility had significant improved total cob $\left(53.66 \mathrm{q} \mathrm{ha}^{-1}\right)$ and baby corn yield (13.92 q $\left.\mathrm{ha}^{-1}\right)$ and green fodder yield $\left(278.91 \mathrm{q} \mathrm{ha} \mathrm{h}^{-1}\right)$ with application of 180-90-90 kg NPK ha-1. That might be due to better supply of nutrients, improved growth parameters and 
significant increase in yield attributes of baby corn. Saha and Mondal (2006), Panwar and Munda (2006), Singh and Choudhary (2008), Sahoo and Mahapatra (2007) and Panwar (2008) further advocated similar effect of fertility as it has been observed in the present study.

Zinc significantly improved green fodder yield $\left(277.7 \mathrm{q} \mathrm{ha}^{-1}\right)$ with successive increase in zinc level up to $5.0 \mathrm{~kg} \mathrm{Zn} \mathrm{ha}{ }^{-1}$. However, total cob (51.61 $\left.\mathrm{q} \mathrm{ha}^{-1}\right)$ and baby corn yield (13.38 $\mathrm{q}$ ha $^{-1}$ ) could not vary significantly with application of $5.0 \mathrm{~kg} \mathrm{Zn} \mathrm{ha-1.} \mathrm{This} \mathrm{might} \mathrm{be}$ due to zinc involved in various metabolic functions and enhances synthesis of growth hormones and protein. It is needed in the production of chlorophyll and metabolism of carbohydrate, may be resulted in higher chlorophyll contents and higher yield attributes, and this had apparently a positive effect on photosynthetic activity, synthesis of metabolites and growth-regulating substances, oxidation and metabolic activities and ultimately better growth and development of crop, which led to increase in yield attributes and yield of baby corn. The results were in conformity with Meena et al. (2013), Shivay and Prasad (2014). Zinc fertilization has beneficial effect on physiological process, plant metabolism and plant growth, which leads to higher yield. Increase in cob and corn yield with application of zinc was also reported by Kumar and Bohra (2014).

\section{Effect of plant geometry, graded fertility and zinc on economics of baby corn}

Perusal of data (Table 1) reveals that highest net returns (Rs 225774 ha $^{-1}$ ) profitability (Rs $3722 \mathrm{ha}^{-1}$ day $^{-1}$ ) and B:C ratio 5.12 had found in paired row plant geometry. The planting geometry of paired row was attributed due to higher total cob yield and baby corn yield. The results collaborate with the findings of Kumar (2008).
Increase in fertility level upto $180-90-90 \mathrm{~kg}$ NPK ha ${ }^{-1}$ significantly fetched higher net returns (Rs $219108 \mathrm{ha}^{-1}$ ) and B:C ratio 4.81 and higher profitability (Rs 3625 ha $^{-1}$ day $^{-1}$ ). This was attributed due to higher yield attributes, baby corn yield and green fodder yield. Similar finding was reported by Jeet $e t$ al., (2014) reported highest net return and B: $\mathrm{C}$ ratio was recorded under $150 \mathrm{~kg} \mathrm{~N} \mathrm{Na}^{-1}$ in QPM hybrids. In the same way, Kumar et. al., (2014) reported that yield of cob, corn and green fodder besides gross return, net return and benefit cost ratio increased significantly with application of $125 \%$ RDF (recommended dose of fertilizer) over $100 \%$ RDF.

Zinc level had improved gross return and net return with successive increase in zinc level up to maximum level $5.0 \mathrm{~kg} \mathrm{Zn} \mathrm{ha}{ }^{-1}$. Higher gross return (Rs 256212), net return (Rs 219108) and higher profitability (Rs $3525 \mathrm{ha}^{-1}$ day $^{-1}$ ) was recorded with application of $5.0 \mathrm{~kg}$ $\mathrm{Zn} \mathrm{ha}^{-1}$, this might be due to higher yield attributes and green fodder yield of baby corn.

\section{Effect of plant geometry, graded fertility and zinc on quality of baby corn}

The quality parameters were affected with plant geometry and was noticed significantly higher values of reducing sugar (5.93\%), protein (16.59\%), Nitrogen (2.672\%), Phosphorous $(0.675 \%)$, potassium $(2.599 \%)$ and Zinc (30.92 ppm) in baby corn with paired row plant geometry.

The wider crop geometry had helped the individual plants to make better spatial utilization of available moisture, nutrients and higher interception of solar radiation with lesser competition which contributed towards more dry matter production per plant and ultimately enhancement of the quality parameter of baby corn. 
Table.1 Effect of plant geometry, graded fertility and zinc level on yield and economics of baby corn

\begin{tabular}{|c|c|c|c|c|c|c|c|}
\hline Treatments & $\begin{array}{c}\text { Baby cob } \\
\text { yield } \\
\left(\text { q ha }^{-1}\right)\end{array}$ & $\begin{array}{c}\text { Baby corn } \\
\text { yield } \\
\left(\mathbf{q} \mathbf{h a}^{-1}\right)\end{array}$ & $\begin{array}{c}\text { Green } \\
\text { fodder yield } \\
\left(\mathbf{q} \mathbf{h a}^{-1}\right)\end{array}$ & $\begin{array}{c}\text { Gross } \\
\text { return } \\
\left(\text { Rs ha }^{-1}\right)\end{array}$ & $\begin{array}{l}\text { Net return } \\
\left(\text { Rs ha }^{-1}\right)\end{array}$ & B:C Ratio & $\begin{array}{l}\text { Profitability } \\
\text { (Rs/ha/day) }\end{array}$ \\
\hline \multicolumn{8}{|l|}{ Plant geometry } \\
\hline$P_{1}(40 \times 20 \mathrm{~cm})$ & 50.77 & 13.06 & 265.20 & 248949 & 204868 & 4.64 & 3428 \\
\hline$P_{2}(50 X 15 \mathrm{~cm})$ & 46.90 & 12.09 & 284.24 & 238223 & 193782 & 4.35 & 3261 \\
\hline $\mathbf{P}_{3}($ Paired row $)$ & 54.91 & 14.34 & 267.82 & 269855 & 225774 & 5.12 & 3722 \\
\hline $\mathbf{S E m} \pm$ & 0.84 & 0.21 & 3.58 & 2944 & 2944 & 0.07 & 32 \\
\hline $\mathrm{CD}(\mathrm{P}=0.05)$ & 3.30 & 0.83 & 14.05 & 11560 & 11560 & 0.26 & 126 \\
\hline \multicolumn{8}{|c|}{ Fertility level $\left(\mathrm{N}: \mathrm{P}_{2} \mathrm{O}_{5}: \mathrm{K}_{2} \mathrm{O} \mathrm{kg} \mathrm{ha}^{-1}\right)$} \\
\hline$F_{1}(120: 60: 60)$ & 46.87 & 12.05 & 266.10 & 235512 & 192642 & 4.49 & 3244 \\
\hline$F_{2}(150: 75: 75)$ & 52.04 & 13.52 & 272.25 & 256875 & 212673 & 4.81 & 3543 \\
\hline$F_{3}(180: 90: 90)$ & 53.66 & 13.92 & 278.91 & 264641 & 219108 & 4.81 & 3625 \\
\hline S Em \pm & 0.59 & 0.12 & 1.34 & 2606 & 2606 & 0.06 & 45 \\
\hline $\mathrm{CD}(\mathrm{P}=\mathbf{0 . 0 5})$ & 1.81 & 0.37 & 4.14 & 8031 & 8031 & 0.18 & 138 \\
\hline \multicolumn{8}{|c|}{ Zinc level (Zn kg ha $\left.{ }^{-1}\right)$} \\
\hline $\mathrm{Z}_{1}(\mathbf{2 . 5 )}$ & 50.11 & 12.95 & 267.14 & 248473 & 204461 & 4.64 & 3416 \\
\hline $\mathrm{Z}_{2}(\mathbf{5 . 0})$ & 51.61 & 13.38 & 277.70 & 256212 & 211821 & 4.77 & 3525 \\
\hline S Em \pm & 0.52 & 0.13 & 0.94 & 1999 & 1999 & 0.05 & 35 \\
\hline $\mathrm{CD}(\mathrm{P}=0.05)$ & NS & NS & 2.78 & 5939 & 5939 & NS & 103 \\
\hline
\end{tabular}


Table.2 Effect of plant geometry, graded fertility and zinc level on quality of baby corn

\begin{tabular}{|c|c|c|c|c|c|c|c|c|}
\hline Treatments & $\begin{array}{r}\text { Reducing } \\
\text { sugar }(\%)\end{array}$ & $\begin{array}{c}\text { Non- } \\
\text { reducing } \\
\text { sugar }(\%)\end{array}$ & $\begin{array}{c}\text { Total } \\
\text { sugar } \\
(\%)\end{array}$ & $\begin{array}{l}\text { Protein } \\
\text { in baby } \\
\text { corn }(\%)\end{array}$ & $\begin{array}{l}\text { Nitrogen } \\
(\%)\end{array}$ & $\begin{array}{c}\text { Phosphorous } \\
(\%)\end{array}$ & $\begin{array}{c}\text { Potassium } \\
(\%)\end{array}$ & Zinc (ppm) \\
\hline \multicolumn{9}{|l|}{ Plant geometry } \\
\hline$P_{1}(40 \times 20 \mathrm{~cm})$ & 5.83 & 0.93 & 6.76 & 15.76 & 2.530 & 0.595 & 2.428 & 29.65 \\
\hline$P_{2}(50 X 15 \mathrm{~cm})$ & 5.76 & 0.94 & 6.70 & 14.99 & 2.414 & 0.542 & 2.237 & 24.98 \\
\hline $\mathbf{P}_{3}($ Paired row $)$ & 5.93 & 0.94 & 6.87 & 16.59 & 2.672 & 0.675 & 2.599 & 30.92 \\
\hline S Em \pm & 0.02 & 0.10 & 0.11 & 0.30 & 0.046 & 0.010 & 0.068 & 1.13 \\
\hline $\mathrm{CD}(\mathrm{P}=\mathbf{0 . 0 5})$ & 0.09 & NS & NS & 1.17 & 0.179 & 0.040 & 0.267 & 4.45 \\
\hline \multicolumn{9}{|c|}{ Fertility level $\left(\mathrm{N}: \mathrm{P}_{2} \mathrm{O}_{5}: \mathrm{K}_{2} \mathrm{O} \mathrm{kg} \mathrm{ha}^{-1}\right)$} \\
\hline$F_{1}(120: 60: 60)$ & 5.69 & 0.85 & 6.54 & 13.59 & 2.189 & 0.586 & 2.342 & 32.02 \\
\hline$F_{2}(150: 75: 75)$ & 5.88 & 0.92 & 6.80 & 15.72 & 2.528 & 0.595 & 2.409 & 27.57 \\
\hline$F_{3}(180: 90: 90)$ & 5.95 & 1.04 & 6.99 & 18.03 & 2.899 & 0.632 & 2.514 & 25.97 \\
\hline S Em \pm & 0.02 & 0.03 & 0.04 & 0.16 & 0.022 & 0.005 & 0.021 & 0.46 \\
\hline $\mathrm{CD}(\mathrm{P}=0.05)$ & 0.06 & 0.11 & 0.11 & 0.49 & 0.067 & 0.015 & 0.063 & 1.40 \\
\hline \multicolumn{9}{|c|}{ Zinc level (Zn kg ha $\left.{ }^{-1}\right)$} \\
\hline$Z_{1}(2.5)$ & 5.81 & 0.89 & 6.70 & 15.27 & 2.455 & 0.606 & 2.396 & 27.41 \\
\hline $\mathbf{Z}_{2}(\mathbf{5 . 0})$ & 5.87 & 0.98 & 6.85 & 16.29 & 2.623 & 0.602 & 2.447 & 29.63 \\
\hline S Em \pm & 0.02 & 0.03 & 0.01 & 0.03 & 0.004 & 0.002 & 0.010 & 0.31 \\
\hline $\mathrm{CD}(\mathrm{P}=0.05)$ & 0.06 & 0.08 & 0.04 & 0.10 & 0.011 & 0.005 & 0.028 & 0.91 \\
\hline
\end{tabular}


The quality parameters were affected significantly due to graded fertility level. The quality parameters viz. reduced sugar $(5.95 \%)$, non-reduced sugar $(1.04 \%)$, protein (18.03\%), Nitrogen (2.899\%), Phosphorous $(0.632 \%)$, potassium $(2.514 \%)$ content in baby corn significantly increased with application of 180-90-90 kg NPK ha ${ }^{-1}$ (Table 2). Consequently, the $\mathrm{N}, \mathrm{P}$ and $\mathrm{K}$ being involved in physico-chemical reactions in plant body of baby corn did behave accordingly to their effect on plant system and enhanced the values of quality parameters. Ramchandrappa et al. (2004a) observed highest values of protein, sugars, N, P and K content in baby corn with application of 150$75-40 \mathrm{~kg}$ NPK ha ${ }^{-1}$. The availability of nutrients elements $(\mathrm{N}, \mathrm{P}, \mathrm{K} \& \mathrm{Zn})$ to the crop plants did occur in balanced and adequate proportion in due course of life of the crop. As for as, nitrogen plays a vital role in division and elongation of plants cells and finally luxuriant growth of the crop. Adequate availability and uptake of phosphorus stimulates the root development which provided better distribution of absorbing network and greater root surface. Potassium promotes the photosynthetic activity, flow of assimilates, translocation and storage of assimilates. The nitrogen, phosphorus and potassium being involved in physicochemical reactions in plant of maize behave accordingly to their effect on plant system and enhanced the values of quality parameters (protein, carbohydrate, sugar and starch) in the present study. Ramachandrappa et al. (2004), Kar et al.(2006) and Muthukumar et al. (2007) also elucidated the facts on the basis of the results obtained in their studies where in, these qualities characters (nutrient content, protein and sugar) got improved due to increase in the levels of $\mathrm{N}, \mathrm{P}, \mathrm{K}$ and $\mathrm{Zn}$ fertilization.

Application of zinc significantly affected the quality parameters of baby corn. It has been noticed that (Table 2) application of $5 \mathrm{~kg} \mathrm{Zn}$ $\mathrm{ha}^{-1}$ significantly improved the quality parameters viz. reduced sugar $(5.87 \%)$, nonreduced sugar $(0.98 \%)$, protein $(16.29 \%)$, Nitrogen (2.623\%), potassium $(2.447 \%)$ content in baby corn over $2.5 \mathrm{~kg} \mathrm{Zn} \mathrm{ha}^{-1}$. The nutrient content $(\mathrm{N}, \mathrm{K}$ and $\mathrm{Zn})$, sugar and protein content increased owing to zinc application which takes part in metabolism of plant as an activator of several enzymes and in turn may directly or indirectly affect the synthesis of carbohydrate and protein. These results are in conformity with the results of Arya and Singh (2000). However, zinc doses could not affect the phosphorous content in baby corn.

It can be concluded that sowing with paired row plant geometry for highest baby corn productivity, profitability and quality of baby corn. Graded fertility level 180:90:90 kg $\mathrm{NP}_{2} \mathrm{O}_{5} \mathrm{~K}_{2} \mathrm{O} / \mathrm{ha}$ a long with $5.0 \mathrm{~kg} \mathrm{Zn} \mathrm{ha}{ }^{-1}$ was found optimum for highest baby corn productivity, profitability and quality of baby corn.

\section{References}

Asif M, Saleem MF, Anjum SA, Wahid MA, Bilal MF (2013). Effect of nitrogen and zinc on growth and yield of maize (Zea mays L.). Journal of Agricultural Reseach 51(4): 455464.

Dadarwal, R. S., Jain, N. K. and Singh, D. 2009. Integrated nutrient management in baby corn (Zea mays). Indian J. Agril. Sci. 79(12): 1023-1025.

Das B, Ranjan JK, Ahmed N, Ranjan Pragya, Mishra BK (2009) Green technology for production of baby corn (Zea mays L) under north west Himalayan conditions. International Journal of Chemical Technology and Research 5 (2):880-885

Kumar Balwinder, Ram H, Dhaliwal SS, Singh ST (2013) Productivity and quality of fodder corn (Zea mays L.) under soil and foliar zinc application XVII International Plant Nutrition Colloquium and Boron Satellite Meeting Proceeding Book 752-753.

Kumar R, Bohra JS (2014) Effect of NPKS and $\mathrm{Zn}$ application on growth, yield, economics 
and quality of baby corn. Achives of Agronomy and Soil science 60(9):1193-1206.

Kumar Rakesh, Bohra JS (2014) Effect of NPKS and $\mathrm{Zn}$ application on growth, yield, economics and quality of baby corn. Achives of Agronomy and Soil science 60(9):11931206.

Kumar, S., Kumar, A., Singh, J. and Kumar, P. 2016. Growth indices and nutrient uptake of fodder maize (Zea mays L.) as influenced by integrated nutrient management. Forage Res. 42(2): 119-123.

Kunjir, S. S.; Chavan, S. A.; Bhagat, S. B. and Zende, N. B. (2007). Effect of planting geometry, nitrogen levels and micronutrients on the growth and yield of sweet corn. Crop Prot. Prod. 2: 25-27.

Mahdi SS, Husain B, Singh L (2012) Influence of seed rate, nitrogen and zinc on fodder maize (Zea mays) in temperate conditions of western Himalayas. Indian

Mathukia RK, Choudhary RP, Shivranand A, Bhosale N (2014) Response of Rabi sweet corn (Zea mays L. var. saccharata Sturt) to plant geometry and fertilizer. Current Advances Agricultural Science 6(2): 196198.

Meena SK, Mundra SL, Singh P (2013) Response of maize (Zea mays) to nitrogen and zinc fertilization. Indian Journal of Agronomy 58(1):127-128.

Panse, V. G. and Sukhatma, P. V. 1985. Statistical methods for Agricultural workers. ICAR Publication, New Delhi, pp. 336-340.

Ramachandrappa, B. K., Nanjappa, H. V. and Shivakumar, H. K. 2004. Yield and quality of baby corn (Zea mays L.) as influenced by spacing and fertilizer levels. ActaAgronomica-Hungarica 52(3): 237-243.

Saha M, Mondal SS (2006) Influence of integrated plant nutrient supply on growth, productivity and quality of baby corn (Zea mays) in Indo-Gangetic Plains. Indian Journal of Agronomy 51: 202-205

Sahoo SC (2011)Yield and economics of baby corn (Zea mays L.) as affected by varieties and levels of nitrogen. Range Management Society of India 32: 135-137.

Shivay YS, Prasad R (2014) Effect of source and methods of zinc application on corn productivity, nitrogen and zinc concentrations and uptake by high quality protein corn ( $\mathrm{Zea}$ mays). Egyptian Journal of Biology 16:72-78.

Singh G, Kumar S, Singh R, Singh SS (2015) Growth and yield of Baby Corn (Zea Mays L.) as influenced by varieties, spacings and dates of sowing. Indian Journal of Agricultural Research 49(4):353- 357.

Singh D, Choudhary J (2008) Effect of plant population and fertilizer levels on yield and economics of popcorn (Zea mays var. indurata). Indian Journal of Agricultural Science 78:370-374.

Thavaprakaash N, Velayudham K (2008) Light interception and productivity of baby corn as influenced by crop geometry intercropping system and INM practices. Asian Journal Of Science Research 1: 72-78.

Thavaprakaash N, Velayudham K, Muthukumar VB (2005) Effect of crop geometry, intercropping system and integrated nutrient management practices on productivity of baby corn (Zea mays L.) based intercropping systems. Research Journal of Agriculture and Biological Sciences 1: 295-302.

Thavaprakaash N, Velayudham K, Muthukumar VB (2008) Response of crop geometry, intercropping systems and INM practices on yield and fodder quality of baby corn. Asian Journal of Pharmaceutical Sciences 1(2): 146-152.

Wasnik, V.K.; Reddy, A.P.K. and Kasbe, Sudhansu, S. (2012). Performance of winter maize under different rates of nitrogen and plant population in Southern Telangana region. Crop Res. 44(3): 269-273.

\section{How to cite this article:}

Alka Jyoti Sharma, M. K. Singh, Sanjay Kumar and Shweta Shambhavi. 2020. Response of Plant Geometry, Graded Fertility and Zinc Level on Productivity, Profitability and Quality of Rainfed Baby corn (Zea mays L.) in Bihar. Int.J.Curr.Microbiol.App.Sci. 9(02): 2085-2092. doi: https://doi.org/10.20546/ijcmas.2020.902.236 